\title{
OXALIC ACID EXCRETION AFTER METHOXYFLURANE AND HALOTHANE ANAESTHESIA*
}

\author{
Donald S. Silverberg, M.D., M.SC., F.R.C.P.(c) $\uparrow$ John W. R. McIntyre, F.F.A.R.C.S., \\ Raymond A. Ulan, M.D., F.R.C.P.(c), and EdWard A. GaiN, M.D., F.R.C.P.(c)
}

Methoxyflurane is a general anaesthetic that has been implicated in the production of postoperative renal dysfunction. ${ }^{1-6}$ The precise mechanism is unknown, but the finding of many oxalate crystals in the renal tubules, ${ }^{5,6}$ and large amounts of oxalic acid in the urine of patients who develop renal failure after methoxyflurane anaesthesia ${ }^{5}$ has suggested the possibility that oxalic acid may be partly responsible.

The present study was undertaken to measure the excretion of oxalic acid and alterations in renal function that occur after methoxyflurane and halothane anaesthesia.

\section{Patients ANd Methods}

Fifteen patients, all of whom had normal renal function prior to their surgery were selected at random. Nine of these were anaesthetized with methoxyflurane and six with halothane. Details of the anaesthesia and surgery in the nine patients receiving methoxyflurane appear in Table I. Nitrous oxide and oxygen were passed through a vaporizer (Pentec), calibrated for methoxyflurane, into a semi-closed circle carbon dioxide absorption system, except in one instance (patient 7), when a non-rebreathing system was employed. The patients were all intubated and artificially ventilated mechanically. The total volume selected for each patient was approximately 50 per cent in excess of the value for the particular patient predicted on the Radford nomogram. Thus, it was unlikely that any patient was hypercarbic during the surgery. Signs suggesting inadequate tissue or organ perfusion did not occur at any time.

Fluids used postoperatively consisted of 5 per cent dextrose in water alternating with 5 per cent dextrose in saline. Total volume of fluids administered daily were between 1500 and $2500 \mathrm{mls}$.

Preoperatively and daily postoperatively the following laboratory measurements were performed: Urinalysis, BuN, serum creatinine, sodium, potassium, chloride, uric acid, bicarbonate, osmolality, calcium, and phosphate. Daily 24-hour urines were collected for determination of protein, creatinine, osmolality, calcium, phosphate, uric acid, and oxalic acid. Urine oxalic acid was measured by a modification of the method of Koch and Strong. ${ }^{7,8}$ The normal values were less than 55 mgm per day.

- Department of Medicine and Department of Anaesthesia, University of Alberta, Edmonton, Alberta.

†Correspondence: Dr. Donald S. Silverberg, Department of Medicine, University of Alberta Hospital, Edmonton, Alberta, Canada. 


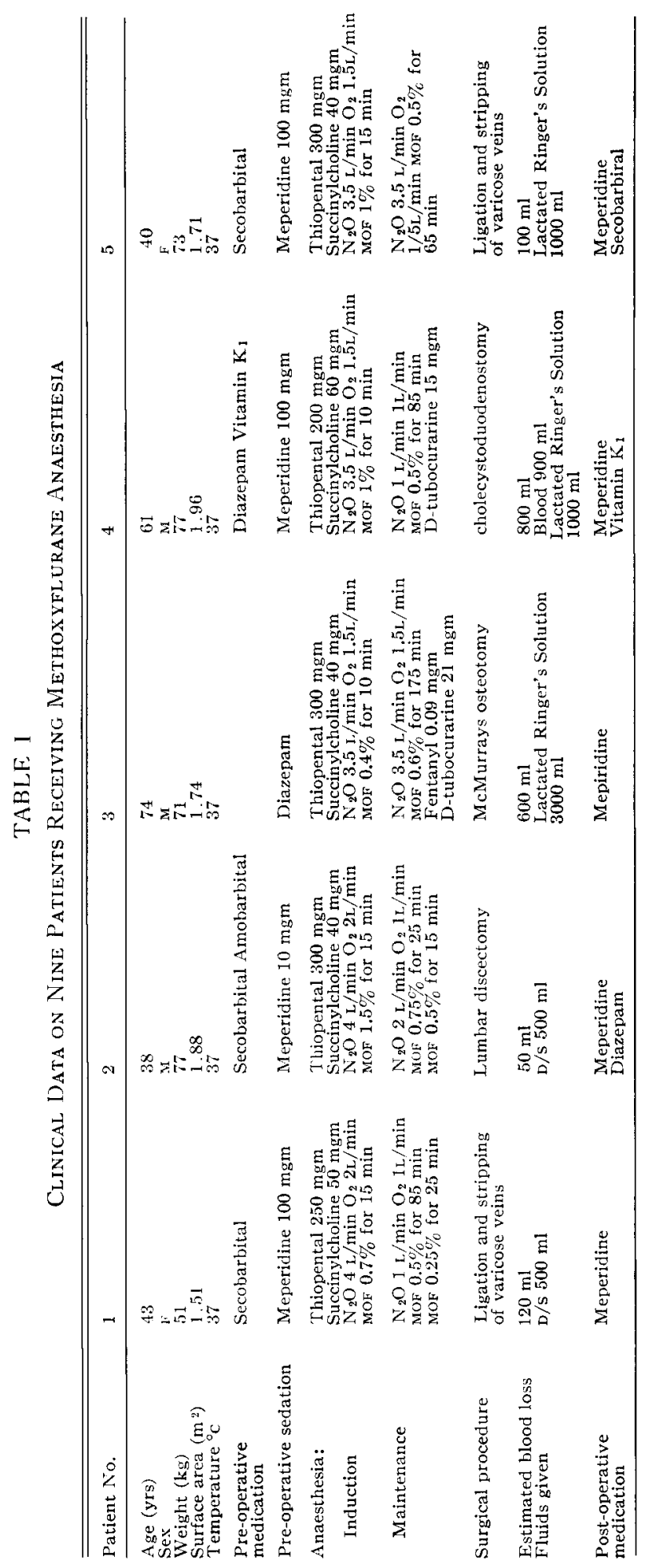




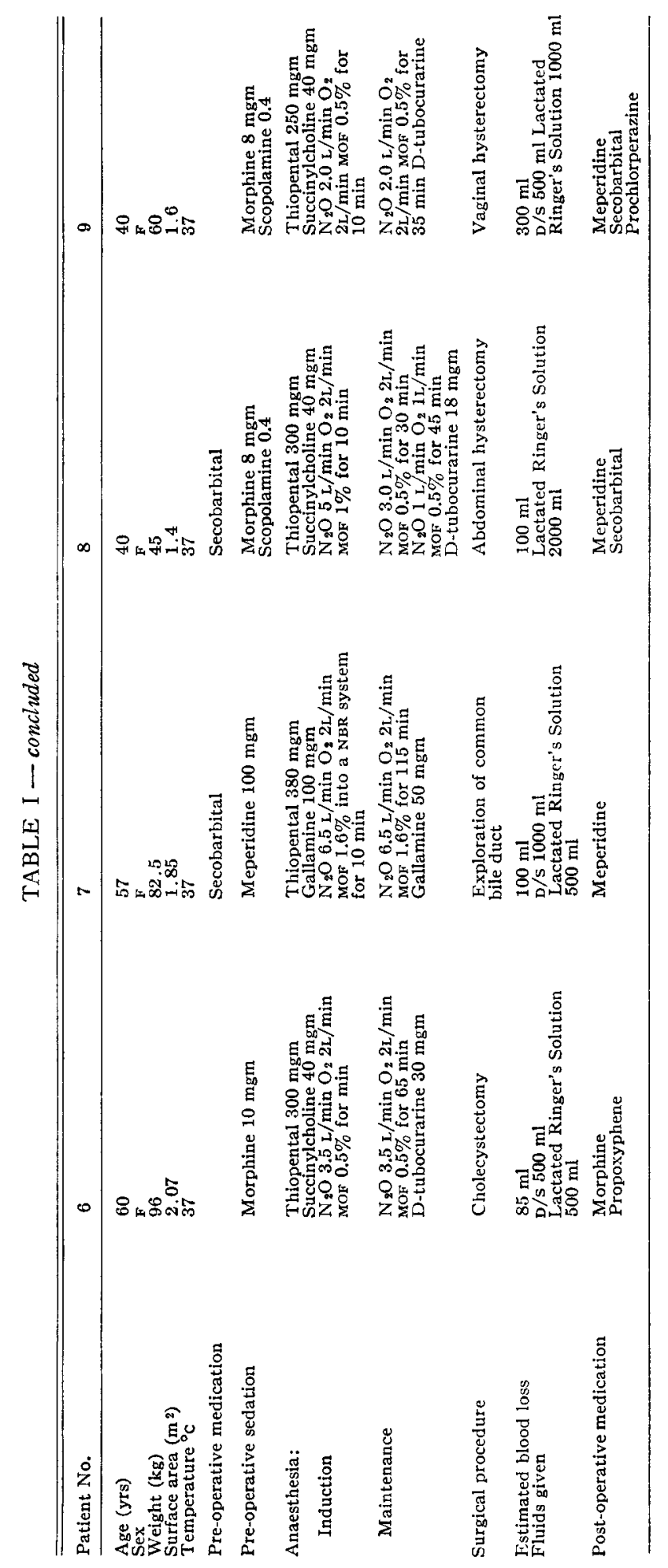




\section{Results}

\section{(1) Oxalic acid excretion (Table II and Figure 1)}

(a) Methoxyflurane Anaesthesia.

Marked hyperoxaluria occurred after anaesthesia in all patients who received methoxyflurane. The highest values were present on the day after operation and decreased slowly thereafter. In five of the nine patients, values had not returned to normal by the seventh day. Preoperative oxalate excretion ranged from 23 to 42 with a mean of 35 . Values on the first postoperative day ranged from 148 to 698 mgm with a mean of $404 \mathrm{mgm}$. By one week the values ranged from 28 to $184 \mathrm{mgm}$ with a mean of $73 \mathrm{mgm}$. (Normal less than $55 \mathrm{mgm}$ per day.) Insufficient data were available to calculate the total quantity of methoxyflurane administered to, and absorbed by any particular patient. However, the details in Table I indicate that patient 7 may have absorbed the greatest amount and it was in this patient that the highest oxalate values were obtained.

TABLE II

Lrinary Oxalate Excretion After Methoxyflurane Anaesthesia

\begin{tabular}{|c|c|c|c|c|c|c|c|c|}
\hline \multirow{2}{*}{$\begin{array}{c}\text { Patient } \\
\text { No. }\end{array}$} & \multirow{2}{*}{$\begin{array}{c}\text { Oxalate } \\
\text { excretion } \\
\text { before } \\
\text { operation } \\
\text { (mgm per day) }\end{array}$} & \multicolumn{7}{|c|}{$\begin{array}{l}\text { Oxalate excretion after operation } \\
\text { days after operation (mgm per day) }\end{array}$} \\
\hline & & 1 & 2 & 3 & 4 & 5 & 6 & 7 \\
\hline 1 & 35 & 380 & $21 \overline{7}$ & 141 & 134 & 84 & 70 & 62 \\
\hline 2 & 23 & 368 & 154 & 80 & 78 & 85 & 80 & 72 \\
\hline 3 & 35 & 400 & 196 & 186 & 170 & 162 & 111 & 101 \\
\hline 4 & 52 & 540 & 390 & 297 & 193 & 190 & 185 & 184 \\
\hline 5 & 36 & 473 & 412 & 138 & 120 & 102 & 104 & 90 \\
\hline 6 & 27 & 243 & 227 & 166 & 99 & 71 & 45 & 40 \\
\hline 7 & 31 & 648 & 550 & 320 & 196 & 126 & 88 & 39 \\
\hline 8 & 30 & 148 & 105 & 84 & 70 & 52 & 32 & 28 \\
\hline 9 & 42 & 389 & 224 & 108 & 60 & 58 & 55 & 44 \\
\hline Mean & 35 & 404 & 276 & 169 & 113 & 103 & 86 & 73 \\
\hline
\end{tabular}

(b) Halothane Anaesthesia (Table III and Figure 1).

No marked alterations in oxalic acid excretion occurred after halothane anaesthesia; the values remaining normal.

\section{(2) Other Laboratory Tests}

No alterations in BUN, serum creatinine, electrolytes, calcium, phosphate, uric acid, or osmolality were noted after either methoxyflurane (Table IV) or halothane anaesthesia. Twenty-four-hour urine excretions of protein, creatinine, calcium, phosphate, and uric acid were unchanged. The osmolar clearances were unchanged. The urinalysis in the postoperative period remained unchanged, except for the presence in the methoxyflurane group of large numbers of oxalate crystals.

\section{Discussion}

In this study there was no alteration in renal function in the postoperative period with either methoxyflurane or halothane. 


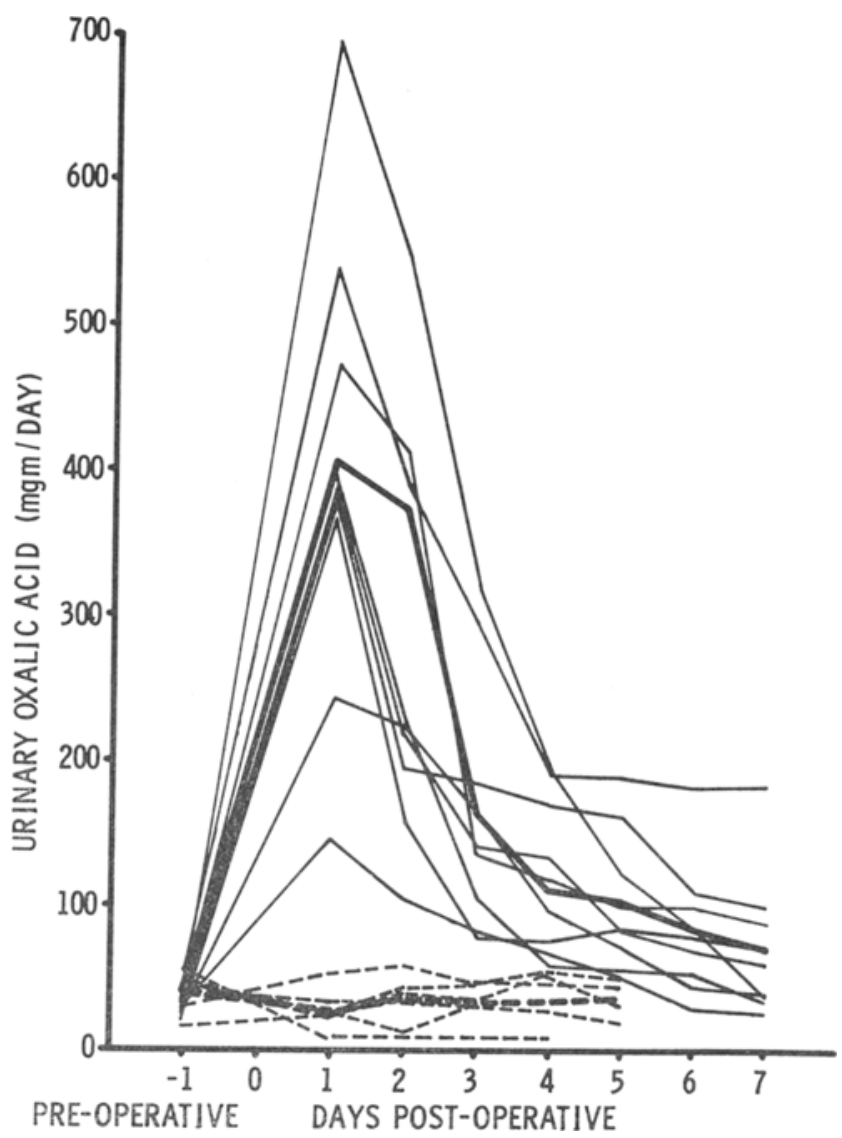

Figure 1. Urinary oxalate excretion after methoxyllurane and halothane anaesthesia. The continuous lines represent the daily urinary oxalic acid excretion after methoxyflurane anaesthesia in nine patients. The heavy continuous line represents the mean value. The interrupted lines represent the daily urinary oxalic acid excretion after halothane anaesthesia in six patients. The heavy interrupted line represents the mean value.

TABLE III

Urinary Oxalate Excretion After Halothane Anaesthesia

\begin{tabular}{|c|c|c|c|c|c|c|c|}
\hline \multirow{2}{*}{$\begin{array}{l}\text { Patient } \\
\text { No. }\end{array}$} & \multirow{2}{*}{$\begin{array}{c}\text { Oxalate } \\
\text { excretion } \\
\text { before } \\
\text { operation } \\
\text { (mgm per day) }\end{array}$} & \multicolumn{6}{|c|}{$\begin{array}{l}\text { Oxalate excretion after operation } \\
\text { days after operation (mgm per day) }\end{array}$} \\
\hline & & 1 & 2 & 3 & 4 & 5 & 6 \\
\hline 10 & 40 & 33 & 31 & 30 & 27 & & \\
\hline 11 & 44 & 22 & 41 & 37 & 53 & 33 & \\
\hline 12 & 31 & 53 & 58 & 48 & 48 & 46 & \\
\hline 13 & 17 & 27 & 42 & 45 & 54 & 52 & \\
\hline 14 & 47 & 27 & 14 & 27 & 24 & 20 & \\
\hline 15 & 55 & 10 & 9 & 10 & 10 & & \\
\hline Mean & 39 & 29 & 33 & 33 & 36 & 38 & \\
\hline
\end{tabular}




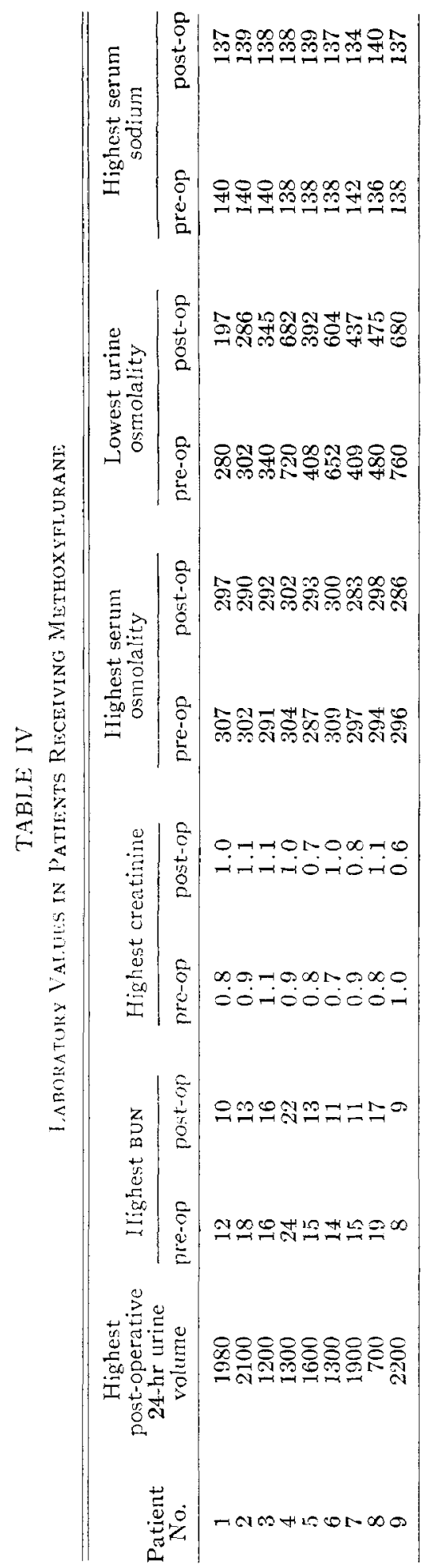


Of greater interest was the difference in oxalic acid excretion between the two groups. Oxalic acid excretion increased from 5 to 23 times in the methoxyfluranetreated group, whereas no change in oxalic acid excretion was seen in the halothanetreated group.

The mechanism or site of production of the hyperoxaluria after methoxyflurane anaesthesia is unknown. A recent study in man ${ }^{9}$ showed that between 29 and 35 per cent of absorbed methoxyflurane is exhaled unchanged, 40 per cent is dechlorinated and oxidized to methoxydifluoracetic acid, and 7 to 21 per cent undergoes cleavage of the ether linkage producing $\mathrm{CO}_{2}$, fluoride ions, and dichloracetic acid. If dechlorination of dichloracetic acid occurs, oxalic acid would be produced. It is also possible that methoxyflurane could interfere with the metabolism of the various precursors of oxalic acid in the liver or intestinal tract, resulting in excessive oxalate production, but these possibilities must await further investigation.

The relationship of oxalic acid excretion and calcium oxalate crystals in the kidney tubules to renal failure is controversial. On the one hand it is known that hyperoxaluria, such as can occur in ethylene glycol intoxication ${ }^{10}$ or congenital hyperoxaluria ${ }^{11}$ can result in failure. Infusion of oxalic acid into animals causes a polyuric renal failure. ${ }^{12}$ However, even in acute and chronic renal failure where no hyperoxaluria has occurred, calcium oxalate crystals are frequently seen within the tubules. ${ }^{13,14}$ Their significance is uncertain. In one study, the finding of crystals did not correlate in any way with the severity of renal disease either histologically or clinically. ${ }^{13}$ In another study a direct correlation was found between the quantity of oxalate crystals in the kidney and the duration of oliguria. ${ }^{14}$ In patients receiving methoxyflurane, oxalate crystals are present in a greater frequency than in those not receiving methoxyflurane, ${ }^{5,6}$ and the more severe the azotaemia, the higher is the proportion of tubules containing oxalate crystals. ${ }^{6}$

The mechanism by which oxalic acid damages the kidneys is uncertain. Galle, ${ }^{15}$ injected large amounts of oxalic acid into rats and studied their deposition in the kidney by light and electron microscopy, and x-ray spectrography. The crystalline deposits first appeared in the cytoplasm of the renal tubular cells. As the crystals grew larger they destroyed the cells and were discharged into the tubular lumen. The crystals may then act to obstruct the lumen directly.

The absence of alteration in renal function during or following the hyperoxaluric state of the patients reported here could indicate that hyperoxaluria plays no part in the etiology of methoxyflurane induced nephrotoxicity. Alternatively greater quantities of oxalic acid may be required in the kidney if demonstrable toxicity is to develop, or additional factors may need to be present. These may include inadequate renal perfusion with blood, inadequate tubular luminal perfusate, and the presence of other drugs. Tetracycline is suspected of having a deleterious effect on renal function when used in patients who have received methoxyflurane anaesthesia. ${ }^{16}$

Methoxyflurane nephrotoxicity has also been attributed to the fluoride ion which is a metabolite of methoxyflurane. ${ }^{17}$ In 1963, Ditzler ${ }^{18}$ questioned the advisability of including the fluorine atom in the structure of anaesthetic drugs. Levels of fluoride in the blood and urine may be very high during and after methoxyflurane 
anaesthesia ${ }^{17}$ and abnormally high fluoride levels can produce a polyuric state in man. ${ }^{19}$

In conclusion, it appears likely that methoxyflurane nephrotoxicity is multifactorial in etiology. The precise role of increased oxalate levels in this syndrome has not yet been elucidated. However, serious consideration should be given to the wisdom of using this agent in those rare patients with congenital hyperoxaluria.

\section{SUMMARY}

Oxalic acid excretion was measured in nine patients receiving methoxyflurane and six patients receiving halothane. Oxalic acid excretion increased from 5 to 23 times in the immediate postoperative period in patients receiving methoxyflurane, whereas no increase was noted in those receiving halothane. Despite the striking increase in oxalic acid excretion, no alteration in renal function and no polyuric state developed. The renal failure that occasionally develops after methoxyflurane anaesthesia appears to be multifactorial in origin and a hyperoxaluric state may play a role in some instances.

\section{RÉSUMÉ}

On a mesuré l'excrétion d'acide oxalique chez neuf malades anesthésiés au méthoxyflurane et six malades anesthésiés au fluothane. L'excrétion d'acide oxalique a autmenté de 5 à 23 fois durant la période post-opératoire chez les malades anesthésiés au méthoxyflurane alors que chez les autres on n'a noté aucune augmentation. Malgré cette augmentation frappante de l'excrétion d'acide oxalique, il ne se produisit pas de changement dans la fonction rénale ni de polyurie. Bien que l'insuffissance rénale qui se produit quelquefois après l'anesthésie au méthoxyflurane semple être dûe à plusieurs facteurs, il semble évident que la dose d'anesthésique administrée peut être un facteur crucial.

\section{REFERENCES}

1. Paddock, R. B.; Parker, J. W.; \& Guadagnt, N. P. The Effects of Methoxylurane in Renal Function. Anesthesiology, 25: 707 (1964).

2. Crandeli, W. B.; Pappas, S. G.; \& Macdonald, A. Nephrotoxicity Associated with Methoxyflurane Anesthesia. Anesthesiology, 27: 591 (1966).

3. Pezzi, P.; Frabege, A. S.; \& Greenberg, S. R. Methoxyflurane and Renal Toxicity. Lancet, I: $823(1966)$.

4. Elkington, S. G.; Goffinet, J. A.; Conn, H. O. Renal and Hepatic Injury Associated with Methoxyflurane Anesthesia. Ann. Int. Med., 69: 1229 (1968).

5. Panner, B. J.; Freeman, R. B.; Roth-Moyo, L. A.; \& Markowitch, W. Jr. Toxicity Following Methoxyflurane Anesthesia (Clinical and Pathological Observations in Two Fatal Cases) J.A.M.A., 214: 86 (1970).

6. Frascino, J. A.; Vanamer, P.; \& Rosen, P. P. Renal Oxalosis and Axotemia After Methoxyflurane Anesthesia. New England J. Med., 283: 676 (1970).

7. Koch, G. H. \& Strong, F. M. Determination of Oxalate in Urine. Analyt Biochem., 27: $162(1969)$.

8. Campbell, D. J. \& Fraser, J. Y. Determination of Urinary Oxalate by Atomic Absorption Spectroscopy. Clin. Biochem. (to be published)

9. Holaday, D. A.; Rudofsky, S., \& Trevilaft, P. S. The Metabolic Degradation of Methoxyflurane in Man. Anesth., 33: 579 (1970). 
10. Fruedman, E. A.; Greenberg, J. B.; Merruli, J. P.; \& Damimin, G. J. Consequences of Ethylene Glycol Poisoning. Am. J. Med., 32: 891 (1962).

11. Williams, H. E. \& Smith, L. H. Disorders of Oxalate Metabollism. Am. J. Med., 45: 715 (1968).

12. Dunn, J. S.; Haworth, A.; \& Jones, N. A. The Pathology of Oxalate Nephritis. J. Path. \& Bact., 27: 299 (1924).

13. Macaluso, M. P. \& Berg, N. O.; Calcium Oxalate Crystals in Kidneys in Acute Tubular Nephrosis and Other Renal Diseases with Functional Failure. Acta path. et microbiol. scandinav. 46: 197 (1959).

14. LAtusch, E. V.; ZuCKer, S.; \& Sovy, R. W. Pathologic Alterations in Uremia Potentiated by Hemodialysis. Clin. Res., 11: 247 (1963).

15. Galle, P. Experimental Renal Oxalosis; Electron Microscopic and X-Ray Spectrographic Study. Nephron, 1: 158 (1964).

16. Kuzucv, E. M. Methoxyfurane, Tetracycline and Renal Failure, J.A.M.A., 211: 1162 (1970).

17. Taves, D. R.; Fry, B. W.; Freeman, R. B.; \& Billies, A. J. Toxicity Following Methoxyflurane Anesthesia. II Fluoride Concentrations in Nephrotoxicity, J.A.M.A., 214: 91 (1970).

18. Ditzler, J. W. Fluorine: Where is it taking us? Anes. \& Analg., 42: 25 (1963).

19. Goldemberg, L. Tratamento de La Enfermedad De Basedow' Y Del Hipertiroidismo Por Fluor. Rev. Soc. Med. Int. Soc. Tisiolog, 6: 217 (1931). 